Uniwersytet Mikołaja Kopernika w Toruniu

Wydział Nauk Ekonomicznych i Zarzqdzania

\title{
Sylwester Bejger
}

\section{DETEKCJA RÓWNOWAGI ZMOWY W BRANŻY Z WYKORZYSTANIEM ANALIZY FALKOWEJ - MODEL TEORETYCZNY}

Z a rys treści. W artykule podjęto próbę weryfikacji możliwości wykorzystania markera zmian strukturalnych wariancji procesu ceny rynkowej w detekcji zmowy graczy w branży. W części pierwszej pracy zaproponowano model teoretyczny zachowań strategicznych graczy w branży przy założeniu egzogenicznych i stałych w czasie kwot kartelowych (udziałów w rynku). Model taki może służyć do wyjaśnienia, między innymi, zachowań graczy w branży producentów Lysiny w latach 1990-1996. Model ten teoretycznie wspiera metodę detekcji zmowy opartą na analizie wariancji procesu ceny rynkowej, motywując niższą wariancję w fazie zmowy. Część druga pracy zawiera weryfikację empiryczną zastosowania markera z wykorzystaniem analizy falkowej.

S łow a kluc z owe : zmowa jawna i milcząca, supergra ze stałą strukturą udziałów w rynku, Lysina, wariancja ceny, analiza falkowa.

\section{WSTĘP}

Jednym z najczęstszych, a zarazem najbardziej destrukcyjnych dla dobra społecznego zachowań graczy w branży jest jawna lub milcząca zmowa, czyli strategicznie wspólne ustalanie cen/udziałów w rynku prowadzące najczęściej do strat bogactwa społecznego (ponadnormalny PCM) oraz ograniczenia konkurencji i zahamowania rozwoju branży (brak bodźców innowacyjno-inwestycyjnych). Zmowa, szczególnie o charakterze jawnym, jest również niebywale szkodliwa dla poczucia bezpieczeństwa konsumentów i ich wiary w system ekonomiczny. 
Aby nadać motywacji dociekań podjętych w niniejszym artykule właściwą wagę, stosowne wydaje się przytoczenie następujących słów: „Jedyną rzeczą jakiej potrzebujemy, jest rozmowa, bo jesteśmy manipulowani przez tych przeklętych odbiorców... Oni nie są waszymi przyjaciółmi. Oni nie są moimi przyjaciółmi... Wy jesteście moimi przyjaciółmi. Chcę być bliżej z wami, niż jestem z jakimkolwiek z moich klientów... I wszystko, czego chcę, to powiedzieć wam jeszcze raz: połóżmy ceny na stół. Niech wszyscy zgodzą się na to, co chcemy zrobić, a potem wyjdźmy stąd i zróbmy to"1.

W niniejszej pracy, złożonej z dwu części, podjęto próbę:

- w części pierwszej - teoretycznego wyjaśnienia obserwowanych zachowań strategicznych graczy w branży, charakterystycznych dla równowagi zmowy na przykładzie rynku producentów Lysiny,

- $\quad$ w części drugiej - aplikacji analizy falkowej w celu empirycznej weryfikacji ustaleń teoretycznych.

\section{DETEKCJA RÓWNOWAGI ZMOWY - MARKERY}

Należy podkreślić, iż praktyczna detekcja zmowy w branży jest zadaniem wyjątkowo trudnym. Z oczywistych względów gracze posiadają przewagę informacyjną nad obserwatorem, dysponując prywatnymi informacjami, którymi nie chcą się dzielić. Teoretyczne modele zmowy jawnej lub milczącej bazujące na właściwych modelach gier (najczęściej supergier o zróżnicowanych założeniach informacyjnych, kodach kar, zróżnicowanej asymetrii graczy oraz wkomponowanych dodatkowych zaburzeniach otoczenia, patrz np.: Athey, Bagwell, 2001; Haltiwanger, Harrington, 1991; Rotemberg, Saloner, 1986; Green, Porter, 1984; Knittel, Lepore, 2010; Leufkens, Peeters, 2009; Yuanzhu, Wright, 2009) są dobrze określone jako hipotezy badawcze dotyczące zachowania graczy². Niestety empiryczna weryfikacja takich modeli nastręcza ogromnych trudności. Biorąc dodatkowo po uwagę fakt, iż zasób statystyki publicznej jest więcej niż skromny na poziomie dezagregacji branżowej lub poszczególnych graczy, szczególnie cenne są metody ekonometryczne z jednej strony oszczędne, jeśli chodzi o wykorzystanie danych statystycznych, z drugiej - spójne z hipotezą modelo-

${ }^{1}$ Cytat pochodzi z inwigilacji kartelu producentów Lysiny prowadzonej przez FBI. Słowa te padły na tajnym spotkaniu czterech przedstawicieli najważniejszych graczy na rynku. Ich sens wydaje się oczywisty, szczególnie w świetle wiedzy o kartelu, jaką posiadamy obecnie. Więcej patrz Griffin (2001), Connor (2000, 2001).

2 Szerzej na temat ogólnej procedury badawczej stopnia monopolizacji branży patrz Bejger (2009b). 
wą . Wśród tych metod obiecująca wydaje się analiza markerów (znaczników) zmowy (zachowań niekonkurencyjnych). Znaczniki te wywodzą się w większości z konstrukcji modelowych cytowanych wyżej i dotyczą charakterystycznych zaburzeń w procesach ekonomicznych, które zmowa wywołuje w sposób określony teoretycznie. Zaburzenia te dotyczą:

- $\quad$ związku pomiędzy cenami proponowanymi przez graczy a zaburzeniami popytu rynkowego,

- stabilności cen i udziałów w rynku graczy,

- związku pomiędzy cenami proponowanymi przez graczy.

\subsection{ZABURZENIA PROCESU CENY RYNKOWEJ CHARAKTERYSTYCZNE DLA RÓWNOWAGI ZMOWY}

Najbardziej oszczędnym ze znaczników zmowy jest znacznik bazujący na analizie pojedynczego procesu, w tym przypadku procesu ceny rynkowej. Odpowiednie dane statystyczne są tu zazwyczaj bezpośrednio obserwowalne lub też możliwe do zgromadzenia niewielkim nakładem sił i środków ${ }^{4}$.

Podstawą specyfikacji każdej metody detekcji równowagi zmowy, także znaczników zmowy, musi być zdaniem autorów właściwy model interakcji strategicznej operujący instrumentarium teorii gier. W zakresie typowych zaburzeń procesu ceny rynkowej modele takie wskazują głównie na zaburzenia w wariancji procesu. Można wskazać trzy najważniejsze specyfikacje modelowe będące źródłem testowalnych hipotez związanych z wariancją ceny.

Rotemberg i Saloner (1990) skonstruowali grę powtarzaną z niekompletną informacją odpowiadającą zjawisku tzw. przywództwa cenowego zmowy (collusive price leadership). Zjawisko to polega na anonsowaniu przez lidera zmiany ceny (zazwyczaj w górę) z pewnym wyprzedzeniem w stosunku do daty jej faktycznego zastosowania. Pozostali uczestnicy rynku naśladują następnie lidera co do wysokości ceny oraz daty jej wprowadzenia. Markham (1951) zasugerował, iż taki schemat zachowań graczy jest mechanizmem pozwalającym na koordynację cen, czyli zmowę bez narażania się na zarzuty karne. Rotemberg i Saloner nadali empirycznym obserwacjom Markhama fundament teoretyczny, konstruując model gry cenowej dla zróżnicowanych produktów z asymetrią informacyjną

3 Próba klasyfikacji metod detekcji m.in. ze względu na stopień eksploatacji danych została podjęta w Bejger (2009b, tabela 1).

${ }^{4}$ Często cena rynkowa nie jest obserwowalna, ponieważ gracze nie publikują cenników, opierając transakcje na cenach negocjowanych z głównymi odbiorcami. Jednak informacje o transakcjach i średnich cenach są zazwyczaj dostępne w źródłach, np. specjalistycznej literaturze branżowej. 
dotyczącą zaburzeń popytu w grze składowej ${ }^{5}$. Zasadniczą, w zakresie tematyki artykułu, konkluzją pracy Rotemberg i Saloner jest stwierdzenie, iż w równowadze skonstruowanej przez nich gry cena rynkowa sterowana przez lidera charakteryzuje się pewną sztywnością, to znaczy niższą wariancją niż w przypadku równowagi konkurencyjnej.

Athey, Bagwell i Sanchirico (2004) zaproponowali model cenowej gry powtarzanej (supergry) z egzogenicznymi zaburzeniami kosztów graczy (stanowiącymi prywatne informacje) oraz obserwowalnymi cenami. Gra jest zatem grą z niekompletną informacją gdzie grę składową stanowi model konkurencji Bertranda $\mathrm{z}$ równowagą Bayesa-Nasha. Autorzy, posługując się własną koncepcją równowagi gry typu $\mathrm{SPPE}^{6}$, wykazali, że w równowadze obserwuje się ceny zmowy oraz że ceny te charakteryzują się sztywnością (w celu utrzymania zmowy). Zatem w fazie zmowy wariancja cen winna być niższa. Należy dodać, iż na ścieżce równowagi nie powinny być obserwowane wojny cenowe (co jest charakterystyczne dla większości standardowych modeli supergier bazujących na strategiach kar).

Maskin i Tirole (1988) wprowadzili model gry powtarzanej z asynchronicznymi wyborami graczy. W grze uczestniczą dwaj gracze, wykonujący ruchy naprzemiennie. Dla przestrzeni akcji będących zbiorami cen, funkcji reakcji typu Markowa $^{7}$ oraz wystarczająco wysokiego czynnika dyskonta istnieje unikalna równowaga Markowa doskonała dla podgier (MPE) Pareto dominująca inne równowagi, która charakteryzuje się sztywną ceną na poziomie ceny monopolowej. Jest to tak zwana cena skupienia (focal price). Mechanizm reakcji strategicznych prowadzących do takiej równowagi jest następujący. Załóżmy, że ceną skupienia jest cena monopolowa $\mathrm{p}^{\mathrm{m}}$. Startując od tej ceny, jeśli rywal podniesie cenę, drugi z graczy nie podąży jego śladem. W przypadku obniżenia ceny do poziomu $\mathrm{p}<\mathrm{p}^{\mathrm{m}}$ drugi z graczy odpowie obniżeniem ceny do poziomu $\mathrm{p}$. Z drugiej strony, jeśli cena spadnie poniżej ceny $\mathrm{p}^{\mathrm{m}}$, optymalną odpowiedzią jest powrót do ceny skupienia. Model Maskin i Tirole jest w istocie prawdziwie dynamiczną wersją mechanizmu złamanej krzywej popytu (kinked demand curve) znanego od lat 30.

5 Modyfikacją tego modelu jest model przywództwa cenowego zmowy dla homogenicznego produktu z ograniczonymi potencjałami produkcyjnymi, patrz Ishibashi (2008). Niestety autor nie zbadał zmian wariancji ceny na ścieżce równowagi.

${ }^{6}$ Akronim Symmetric Perfect Public Equilibrium. Jest to wersja koncepcji równowagi sekwencyjnej, w której gracze warunkują swoje strategie wyłącznie publicznie obserwowalną historią gry (realizacjami cen). Strategie tego typu nazywają się strategiami publicznymi. Strategia taka jest zatem odwzorowaniem ze skończonej przestrzeni historii publicznych $\left\{\rho^{t}\right\}_{t=1}^{\tau} \mathrm{W}$ schematy cen. Ograniczając się dodatkowo do schematów symetrycznych między firmami (dających symetryczne wartości kontynuacji gry dla dowolnego wektora cen etapowych), otrzymuje się SPPE.

7 Są to funkcje postaci $p_{1,2 t+1}=R_{1}\left(p_{2,2 t}\right)$ oraz $p_{2,2 t+2}=R_{2}\left(p_{1,2 t+1}\right)$ dla $t=0,1, \ldots, \infty$. 
XX wieku. Strategie równowagi tego modelu (przy odpowiednich założeniach) implikują zatem małą wariancję ceny w równowadze zmowy.

Reasumując, jeśli znacznik zmowy ma opierać się wyłącznie na analizie procesu ceny, można postawić hipotezę, iż w fazie zmowy wariancja ceny jest średnio niższa niż w fazie konkurencji. Należy się także spodziewać reżimowych zmian wariancji przy przejściu z fazy zmowy do fazy konkurencji, aczkolwiek nie można stwierdzić, czy faza ta jest fazą kary gry powtarzanej, czy też upadkiem kartelu zmowy jawnej spowodowanym innymi przyczynami.

W niniejszej pracy autorzy zbadali możliwość aplikacji wymienionego znacznika zmowy dla szeregu miesięcznych przeciętnych cen Lysiny na rynku USA, obserwowanych w okresie od stycznia 1990 do czerwca 1996 r. W kolejnym rozdziale podano najistotniejsze fakty dotyczące rynku Lysiny w wymienionym okresie. W rozdziale trzecim podjęto próbę specyfikacji modelu gry, który byłby spójny z parametrami branży i zachowaniami graczy. Na podstawie modelu postawiono hipotezy dotyczące zmian w wariancji ceny rynkowej. Artykuł kończy podsumowanie.

Część druga pracy zawiera próbę aplikacji analizy falkowej w celu empirycznej weryfikacji poprawności ustaleń teoretycznych. W rozdziale pierwszym streszczone zostały dotychczasowe badania empiryczne wykorzystujące marker zmian wariancji. Rozdział drugi zawiera opis metodologii badania. W rozdziale trzecim zamieszczono wyniki badania. Artykuł zamyka podsumowanie obu części pracy.

\section{BRANŻA PRODUCENTÓW LYSINY*}

Lysina jest podstawowym aminokwasem używanym w przemysłowej hodowli drobiu, trzody i ryb. Niewielkie ilości są wykorzystywane również w produkcji żywności dla ludzi. Szacuje się np., że indyk gotowy do uboju musi spożyć ok. 1,3 kg Lysiny. Lysina jest związkiem chemicznym, zatem jest produktem homogenicznym. Przemysłowy sposób jej uzyskiwania odkryli naukowcy japońscy w latach 50. XX wieku, natomiast produkcję masową rozpoczął w roku 1960 lider rynku, firma Ajinomoto. Do roku 1980 struktura branży ustabilizowała się na poziomie 3 graczy: Ajinomoto z udziałem około 50\% światowego rynku, Kyowa Hakko (Japonia) - udział około 20\% oraz Miwon (później Sewon, Korea Płd.) z udziałem około 20\%. Gracze ci opanowali także rynek amerykański z udziałami 35 do 40\% Ajinomoto oraz Kyowa i 25\% Sewon. Według zeznań członków władz Ajinomoto producenci Lysiny działali w tamtym okresie w zmowie,

\footnotetext{
* Większość informacji tego podrozdziału oparta jest na Connor (2000).
} 
ustalając ceny, co pozwoliło kształtować cenę 1 funta Lysiny na poziomie około 1,65 USD. O ile trudno datować początek porozumienia, o tyle wydaje się ono bardzo prawdopodobne ze względu na bliskość kulturową graczy, niepełne wykorzystanie potencjału (około 70\%) i poważne bariery wejścia do branży. W 1989 r. amerykańska firma ADM rozpoczęła budowę największej światowej fabryki Lysiny w Decatur, w stanie Illinois. Docelowy potencjał produkcyjny ADM miał wynieść ok. 88\% potencjału Ajinomoto. Produkcję uruchomiono w 1991 roku. W roku tym ceny Lysiny gwałtownie spadły, do poziomu około 0,70 USD. W kwietniu 1992 roku z inicjatywy ADM odbyło się na Hawajach spotkanie (w gronie ADM, Ajinomoto, Kyowa Hakko), na którym przedstawiciel ADM zaproponował „zacieśnienie współpracy” i powołanie „związku producentów aminokwasów” celem ustalania cen Lysiny. Następnie w październiku roku 1993 w Irvine, stan Kalifornia, miało miejsce spotkanie przedstawicieli ADM oraz Ajinomoto (panowie M. Andreas oraz K. Yamada), na którym obaj główni gracze uzgodnili, iż ustalanie cen jest niewystarczające i należy uzgodnić kwoty kartelowe sprzedaży Lysiny (udziały w rynku światowym). Jak się wydaje, porozumienie osiagnięto i zostało ono „parafowane” przez pozostałych graczy w branży na kolejnym spotkaniu w listopadzie w Tokio. Struktura rynku, jaką

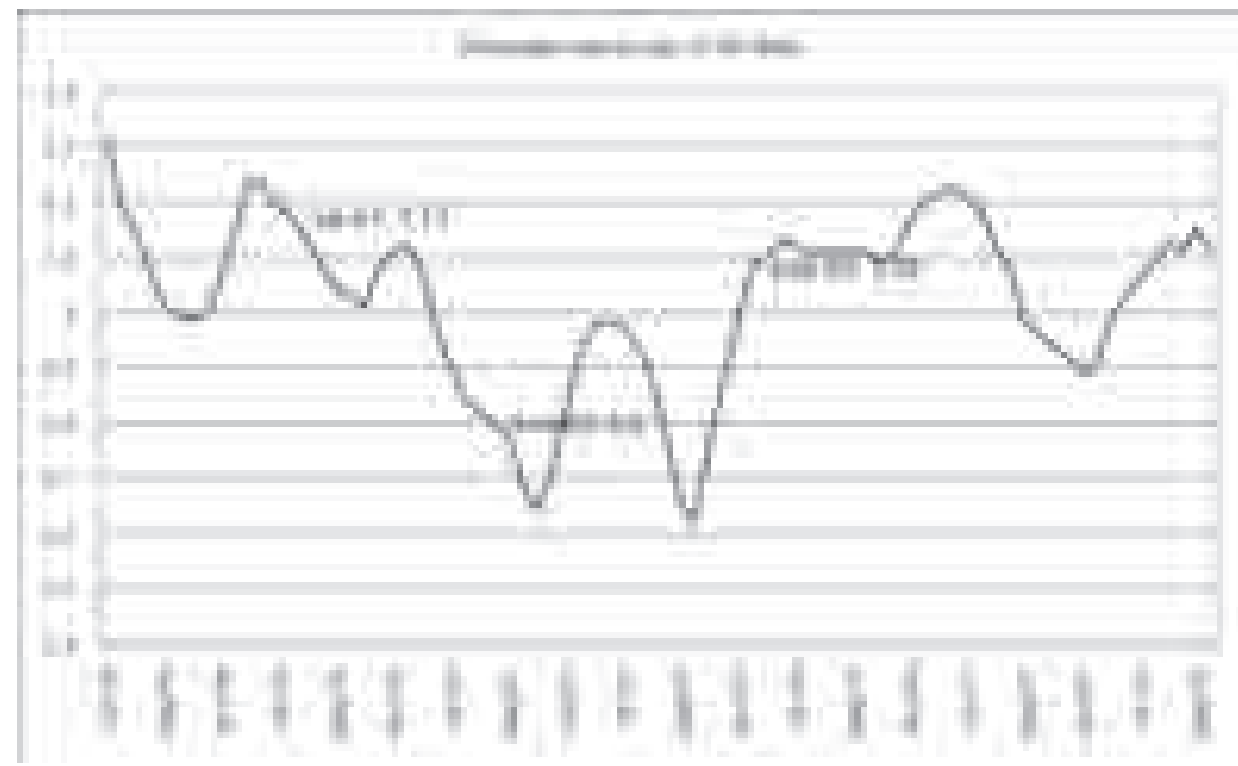

Wykres 1. Przeciętna cena Lysiny na rynku USA

Źródło: opracowanie własne na podstawie danych pochodzących z: Connor (2000), załącznik A, tabela A2. 
wypracowano, dawała ADM większy udział kosztem pozostałych graczy, głównie Sewon i Ajinomoto. Struktura ta ustabilizowała się do roku 1996 na poziomach (średnio) 33\%, 27\%, 18\%, 14\%, 6\% dla Ajinomoto, ADM, Kyowa Hakko, Sewon i Cheil ${ }^{8}$. Wykres 1 (zob. s. 12) ilustruje poziomy cen przeciętnych Lysiny na rynku amerykańskim wraz z naniesionymi datami kluczowych zdarzeń.

W czerwcu 1995 r. FBI przeprowadziło rewizję w siedzibie ADM, zabezpieczając dowody w sprawie zmowy. Dodatkowo ujawniono, iż od roku 1992 w ADM działał zwerbowany przez FBI pracownik M. Whitacre (uzyskał on status świadka koronnego), który dostarczył dużej ilości nagrań audio i video spotkań producentów. W sierpniu 1996 r. trzy azjatyckie firmy uczestniczące w zmowie przyznały się do winy w ramach tzw. leniency program i zgodziły się ujawnić mechanizmy zmowy, a także zeznawać przeciwko ADM. W październiku tego samego roku ADM także przyznał się do zmowy i ustalania cen.

\subsection{KARTEL PRODUCENTÓW LYSINY JAKO PRZYPADEK TESTOWY DLA METOD DETEKCJI ZMOWY}

Zmowa producentów Lysiny jest jednym z tych nielicznych przypadków, gdzie uzyskano potwierdzenie jej istnienia na podstawie zeznań uczestników kartelu․ Można zatem wskazać okresy funkcjonowania branży, w których zmowa miała miejsce z dużym prawdopodobieństwem, i okresy, w których dochodziło do jej zerwania lub zaburzenia. Wychodząc następnie od odpowiednich modeli zachowań strategicznych skutkujących równowagą zmowy, możliwe jest testowanie na podstawie faktycznie zaobserwowanych danych różnorodnych metod detekcji takiej równowagi. Wśród prac o tym charakterze dotyczących branży producentów Lysiny można wymienić: de Roos (2004, 2006); Bolotova, Connor, Miller (2008); Bejger (2009a).

Zasadnicze znaczenie dla wiarygodności weryfikacji metod detekcji, w tym również znacznika opartego na zaburzeniach wariancji ceny rynkowej, jest właściwy model teoretyczny wyjaśniający zachowanie graczy w branży i dający możliwość stawiania testowalnych hipotez dotyczących odpowiednich kategorii ekonomicznych, w tym wariancji procesu ceny. Aby model taki mógł powstać, należy poddać analizie charakterystykę branży oraz znaną historię kartelu w badanym okresie. Branża Lysiny była branżą wysoce skoncentrowana, do roku 1991 obejmująca graczy o zbliżonych (ze względu na lokalizację, technologię i azjatycką kulturę organizacyjną) parametrach kosztowych. Podstawowym wyróżnikiem graczy był potencjał produkcyjny. Istniały wysokie bariery wejścia do

\footnotetext{
8 Niewielki producent indonezyjski, rozpoczął produkcję także w 1991 r.

${ }_{9}$ W Polsce podobnym przypadkiem jest kartel producentów cementu.
} 
branży: opatentowana i utajniona technologia produkcji Lysiny, czas niezbędny na budowę fabryki (powyżej 3 lat), koszty utopione inwestycji (powyżej $150 \mathrm{mln}$ USD). W roku 1989 ADM zasygnalizował, rozpoczynając budowę fabryki, zamiar wejścia do branży. Dalsza historia funkcjonowania branży opiera się na zeznaniach świadków oraz analizie poziomu ceny Lysiny. Wydaje się, iż gracze azjatyccy zaakceptowali wejście do branży, ponieważ w okresie 1989-luty 1991 nie odnotowano spadku cen Lysiny. Można zakładać, że gracze ci zdawali sobie sprawę, iż groźba ADM wejścia do branży jest wiarygodna i ceny drapieżne nie wywołają skutku odstraszenia przed wejściem, a jedynie przyniosą krótkookresowe straty. Jedynym posunięciem graczy azjatyckich (Ajinomoto i Kyowa) było zwiększenie w 1991 r. potencjału produkcyjnego fabryk amerykańskich. W lutym roku 1991 fabryka ADM rozpoczęła produkcję (początkowo z dużymi problemami związanymi z rozruchem nowych linii). Rozpoczęciu produkcji towarzyszył gwałtowny spadek cen Lysiny (z 1,20 USD/lb w styczniu 1991 do 0,64 USD/lb w lipcu 1991). Powszechnie (np. Connor, 2000, 2001; White 2001) uznaje się ten ruch cen za wojnę cenową wywołaną przez ADM (zeznania graczy potwierdzają taką tezę). Następnie od spotkania na Hawajach (ADM proponuje powołanie związku producentów aminokwasów) do marca 1993 r. wyróżnia się fazę zmowy graczy. Zmowa miała polegać na ustalaniu cen. Zakładając, iż to ADM wywołał wojnę cenowa, propozycja powołania związku wydaje się logiczną jej konsekwencją - po fazie konfliktu nastapił czas na porozumienie na warunkach ADM. Trzeba zauważyć, że wszelkie tzw. związki producentów stanowią często wygodną, bo oficjalną, platformę zmowy jawnej ${ }^{10}$. Kolejną faza, trwająca od marca 1993 do września 1993 r., jest następna wojna cenowa. Identyfikują tę fazę zeznania świadków (wywołać wojnę miały trudności w monitoringu cen, nieufność graczy względem siebie, a przede wszystkim brak podziału kwot kartelowych) oraz w mniejszym stopniu ruch poziomu cen. W październiku dochodzi do spotkania w Irvine, gdzie (wg zeznań świadków) uzgodnione zostają kwoty kartelowe oraz skuteczne sposoby monitoringu uzgodnionych udziałów. Rozpoczyna się faza zmowy, mająca swoje odbicie także w wyraźnym wzroście cen. Jako zakończenie tej fazy w sposób nieco automatyczny przyjmuje się początek oficjalnego śledztwa prowadzonego przez FBI, czyli czerwiec 1995 r.

10 W polskiej praktyce koronny przykład to Stowarzyszenie Producentów Cementu i jego rola w wymianie poufnych informacji handlowych w tzw. grupie 7, czyli w kartelu producentów cementu. Szerzej patrz: Decyzja Prezesa UOKiK z dnia 8 grudnia 2009 r., nr DOK - 7/09, punkt V.I.1, s. 23. 


\section{MODEL TEORETYCZNY FUNKCJONOWANIA BRANŻY PRODUCENTÓW LYSINY}

Zasadniczym etapem detekcji faz zmowy w branży winien być etap konstrukcji modelu gry, której równowaga jest spójna z obserwowanym zachowaniem graczy, pozwalającego na formułowanie hipotez weryfikowalnych empirycznie. W przypadku branży producentów Lysiny należy wskazać taki model gry, który:

- będzie zawierał wyjaśnienie wojny cenowej wywołanej przez ADM po wejściu do branży,

- pozwoli na predykcję zachowań graczy w zakresie ustalania cen zmowy, tak aby możliwa była analiza zmian wariancji.

Cytowana wcześniej literatura związana z modelami zmowy opartymi na grach dynamicznych zawiera wiele propozycji takich modeli (krytyczną analizę niektórych z nich, aplikowanych do branży producentów Lysiny zawiera praca de Roos (2006)), jednak strategie równowagi żadnego z nich nie obejmują wojny cenowej przy wejściu do branży oraz późniejszego okresu zmowy. Wydaje się, iż kluczem do stworzenia zadowalającego modelu supergry jest przyjęcie właściwych założeń, związanych ze sposobem działania kartelu. Najistotniejsza w tym zakresie jest obserwacja poczyniona przez de Roos (2004). Autor ten zauważył, że mechanizm zmowy nie musi zawierać żadnych skomplikowanych sposobów podziału rynku, wynikających wprost z interakcji strategicznych równowagi zmowy milczącej. Może za to być oparty na prostej „regule kciuka” - kontyngenty zmowy są stałe (w sensie udziałów w rynku), a ich struktura w momencie zawiązania zmowy jest po prostu zastanym na rynku status quo. Obserwacja ta wydaje się niezwykle trafna, na podobnej zasadzie działał np. wspomniany już kartel producentów cementu w Polsce. W pracy de Roos (2004) autor zbudował model gry dynamicznej w przestrzeni stanów, uzyskując poprzez symulacje ścieżki równowagi zawierające zarówno fazy wojny cenowej, jak i fazy zmowy na rynku o zmiennej liczbie graczy. Co więcej, statystyka symulacji wskazuje na to, iż gracz wchodzący na rynek najpierw dąży do zdobycia udziału w rynku porównywalnego do udziałów jego konkurentów, zanim zdecyduje się przyłączyć do zmowy. Wyniki te w dużej mierze mogą wyjaśniać historię kartelu Lysiny. Niestety model ten nie jest oparty na standardowym modelu supergry i nie zawiera analitycznie określonych warunków równowagi zmowy. Dodatkowo, nie zawiera także żadnych wskazań co do zachowania wariancji ceny rynkowej przy przejściu pomiędzy fazami konkurencji i zmowy, co jest istotne w kontekście znaczników zmowy. Autorzy niniejszej publikacji podjęli próbę stworzenia konstrukcji modelowej, która uzupełniłaby wymienione braki. 


\subsection{ZAŁOŻENIA MODELU}

Przyjmijmy, że na rynku funkcjonuje $n$ graczy. Dana jest funkcja odwrotna do funkcji popytu $\mathrm{P}(\mathrm{Q})$. Załóżmy, iż jest to funkcja liniowa postaci $p=a-b Q$, przy czym $\mathrm{Q}=\mathrm{q}_{1}+\mathrm{q}_{2}+\ldots+\mathrm{q}_{\mathrm{n}}$, gdzie $q_{i}$ oznacza podaż gracza $i$. Określona jest funkcja kosztów graczy $C_{i}\left(q_{i}\right)$. Załóżmy symetrię graczy (ta sama technologia wytwarzania), przyjmijmy postać liniową funkcji kosztów $C=q_{i}$ dla $i=1,2, \ldots, n$ oraz $c=$ const. Zakładamy także, iż $a>c>0$.

Załóżmy dalej, że interakcje strategiczne graczy w branży wystarczająco poprawnie może opisać model gry powtarzanej w nieskończonym horyzoncie, a strategie przełącznikowe z karą permanentną Nasha dobrze opisują zachowanie graczy. Właściwy model gry zdefiniowano poniżej.

\subsection{MODEL GRY ZMOWY ZUPEŁNEJ}

\section{Gra skladowa $g$}

Zakłada się, że gra składowa jest skończoną statyczną grą niekooperacyjną o kompletnej informacji. W grze uczestniczy skończony zbiór $G=\{1,2, \ldots, n\}$ graczy. Każdy z graczy posiada skończona, wypukłą i zwartą przestrzeń wyborów (akcji) $Q_{i}$ oraz dobrze określoną funkcję wypłaty gry składowej:

$$
\pi_{i}: Q \rightarrow R
$$

gdzie: $Q=\times_{i \in G} Q_{i}$.

Wyborami graczy są poziomy podaży $q_{i}$.

Postać analityczna funkcji wypłaty gracza $i$ dana jest jako:

$$
\pi_{i}=[a-b Q] q_{i}-c q_{i} .
$$

Opierając się na wprowadzonym przez Seltena odwzorowaniu skumulowanej najlepszej odpowiedzi:

$$
\begin{aligned}
& N_{i}^{\text {cum }}\left(s_{a}\right)=\left\{s_{i} \in S_{i}: s_{i} \in N_{i}\left(s_{a}-s_{i}\right)\right\}, \\
& \text { gdzie: } s_{a}=\sum_{i=1}^{n} s_{i},
\end{aligned}
$$

oraz uwzględniając symetrię graczy, można sformułować funkcje reakcji postaci:

$$
R_{i}\left(Q_{-i}\right)=\frac{a-c-b Q_{-i}}{2 b}, \quad i=1, \ldots, n,
$$

gdzie: $Q_{-i}=(n-1) q_{i}$. 
Dla tak określonego systemu funkcji reakcji (4) gry składowej $g$ istnieje unikalny profil akcji czystych:

$$
q_{i}^{N C}=q^{N C}=\frac{a-c}{(n+1) b}
$$

w równowadze Nasha ${ }^{11}$.

Gracze w równowadze (5) otrzymują wypłaty:

$$
\pi_{i}^{N C}=\pi^{N C}=\frac{(a-c)^{2}}{(n+1)^{2} b} .
$$

Wektory podaży (5) oraz wypłat (6) odpowiadają zatem równowadze Nasha symetrycznego oligopolu typu Cournota, stąd superskrypt NC dla wypłat. Podaż (5) zwyczajowo określa się jako podaż kary.

Załóżmy dalej, iż gracze w branży mają określone egzogenicznie udziały ilościowe w rynku ${ }^{12}$ :

$$
s_{i}=\frac{q_{i}}{Q} .
$$

Dla zagregowanego systemu funkcji wypłat (2):

$$
\Pi=[a-b Q] Q-c Q
$$

istnieje unikalna podaż branży:

$$
Q^{m}=\frac{a-c}{2 b}
$$

maksymalizująca wartość (8). Nazwijmy tę podaż podażą monopolową, a wypłatę zagregowaną wypłatą monopolową $\Pi^{m}$. Podaż branży (9) odpowiada całkowitej zmowie graczy. W przypadku symetrycznych kontyngentów zmowy każdy z graczy realizowałby wypłatę równą $\frac{\Pi^{m}}{n}$. Jednakże dla ustalonych egzogenicznie kontyngentów (7) wypłata zmowy reprezentatywnego gracza będzie równa:

$$
\pi_{i}^{z}=\left[\left(a-b\left(\frac{a-c}{2 b}\right)\right) *\left(s_{i}\left(\frac{a-c}{2 b}\right)\right)\right]-c\left(s_{i}\left(\frac{a-c}{2 b}\right)\right)=\frac{1}{4 b} s_{i}(a-c)^{2} .
$$

11 Profil ten istnieje z uwagi na quasi-wklęsłość $\pi_{\mathrm{i}}$ ze względu na $\mathrm{q}_{\mathrm{i}}$, co jest warunkiem koniecznym i wystarczającym.

12 Dla uproszczenia rachunków zakłada się, iż $\sum_{i=1}^{n} s_{i}=1$, czyli pomija się tzw. skrzydło konkurencyjne, a więc pewną liczbę małych graczy niemających siły rynkowej. 
Zauważmy dalej, iż podaże kartelowe $q_{i}^{z}=s_{i}\left(\frac{a-c}{2 b}\right)$ nie są wzajemnie najlepszymi odpowiedziami graczy, tj. nie są profilem w równowadze Nasha gry składowej. Można wskazać najlepszą odpowiedź gracza, tzn. taka, że:

$$
N_{i}\left(Q_{-i}^{z}\right)=\left\{q_{i}^{O} \in Q_{i}: q_{i}^{O} \in \underset{q_{i} \in Q_{i}}{\arg \max } \pi_{i}\left(q_{i}, Q_{-i}^{z}\right)\right\} .
$$

Na mocy (3) możemy zdefiniować:

$$
Q_{-i}^{z}=\left(1-s_{i}\right)\left(\frac{a-c}{2 b}\right),
$$

co pozwala zapisać funkcję wypłaty jako:

$$
\pi_{i}=\left[\left(a-b\left(q_{i}+\left(1-s_{i}\right)\left(\frac{a-c}{2 b}\right)\right)\right] * q_{i}-c q_{i} .\right.
$$

Różniczkując (13) ze względu na $q_{i}$ i rozwiązując warunek I rzędu, otrzymujemy najlepszą odpowiedź gracza $i$ :

$$
q_{i}^{O}=\frac{1}{4 b}\left(a-c+a s_{i}-c s_{i}\right) .
$$

Podaż ta nazywana jest podażą odstępstwa gracza o kontyngencie $s_{i}$ (stąd superskrypt O). Podaży tej odpowiada wypłata odstępstwa gracza o kontyngencie $s_{i}$ :

$$
\pi_{i}^{O}=\frac{1}{16 b}(a-c)^{2}\left(s_{i}+1\right)^{2} .
$$

Przyjmując, celem korekty uzyskanych wyników analitycznych, parametryzację rynku Lysiny oszacowaną przez de Roos (de Roos, 2004, tablica 1, s. 368) $\mathrm{a}:=1,651$, b: $=0,0857, \mathrm{c}:=0,527$ oraz zakładając $\mathrm{s}_{\mathrm{i}}:=0,3, \mathrm{n}:=3$, otrzymujemy: $\pi^{N C}=0,921 ; \pi^{Z}=1,105 ; \pi^{O}=1,557$, co jest zgodne $\mathrm{z}$ teoria.

\section{Gra powtarzana $\Gamma(T)$}

Gra powtarzana w nieskończonym horyzoncie polega na powtórzeniu gry składowej $g \mathrm{w}$ T etapach, gdzie $\mathrm{T}=\infty$. W etapie $t$ gracze rozgrywają grę składową $g$, a więc dokonują wyborów $q_{i} \in \mathrm{Q}_{\mathrm{i}}$. Wybory graczy są obserwowalne, z pewnym okresem opóźnienia detekcji $\Delta$. Gra $\Gamma$ (T) jest zatem grą z prawie doskonałą informacją. Oznacza się profil wyborów etapu $t$ poprzez $\boldsymbol{q}^{t}$. Dany jest zatem zbiór:

$$
H^{t}=(Q)^{t}
$$

historii $h^{t}$ gry do etapu $t$. Dodatkowo dla $t=0, h^{0}=\varnothing$. 
Określony jest także zbiór $H^{\infty}$ historii końcowych $h^{\infty}$ gry. Strategią czystą $S_{i}$ gracza $i$ jest sekwencja odwzorowań $\left(S_{i}^{t}\right)_{t=0}^{\infty}$

$$
S_{i}^{t}: H^{t} \rightarrow Q_{i}
$$

(jedno dla każdego okresu $t$ ), które odwzorowują możliwe historie $h^{t} \in H^{t} \mathrm{w}$ wybory $q_{i} \in Q_{i}$.

Dla gier konkurencji oligopolistycznej naturalnym rodzajem preferencji graczy są określone na historiach końcowych gry $h^{\infty}$ preferencje z dyskontem. Wprowadza się zatem czynnik dyskontujący:

$$
\delta=\frac{1}{(1+r)}=\mu e^{-l \Delta}
$$

gdzie:

l - stopa dyskonta,

$\mu$ - warunkowe prawdopodobieństwo kontynuacji gry w okresie $t$ lub inaczej stopa pewności kontynuacji gry (ang. hazard rate),

$\Delta-$ długość okresu (opóźnienie detekcji).

Czynnik dyskontujący $\delta$ jest stały w czasie oraz objęty wiedzą wspólną. Funkcje wypłat gry powtarzanej dla strategii czystych i preferencji z dyskontem określone są jako:

$$
\Pi_{i}=\sum_{t=0}^{\infty} \delta^{t} \pi_{i}\left(q^{t}\right)
$$

\section{Strategie w równowadze gry powtarzanej}

Dla opisanego modelu powtarzanej interakcji strategicznej zakłada się użycie przez graczy następujących strategii w sensie (15):

$$
S_{i}=\left\{\begin{array}{c}
q_{i}^{t}=q_{i}^{z}, \quad \text { gdy } \quad q_{j}^{\tau}=q_{j \neq i}^{z} \quad \text { dla } \tau=0, \ldots, t-1 \\
q_{i}^{t}=q_{i}^{N C} \\
q_{j}^{\tau}=q_{j \neq i}^{O} \quad \text { dla } \tau=0, \ldots, t-1 .
\end{array}\right.
$$

Strategia typu (18) jest strategią przełącznikową z karą permanentną Nasha. Zwyczajowo jej sens jest werbalizowany następująco: realizuj podaż zmowy dopóty, dopóki konkurencja nie odstapi od jej realizacji poprzez zastosowanie dającej wyższą wypłatę podaży odstępstwa. Jeśli tak się stanie, od następnego etapu gry realizuj podaż kary.

Aby strategie (18) supergry były w równowadze Nasha, muszą spełniać warunek Seltena doskonałości dla podgier. Profil tych strategii spełnia ten warunek, jeśli tylko obecna wartość strumienia wypłat (10) dla replikacji profilu zmowy $q^{z}$ 
przewyższa obecną wartość strumienia wypłat dla uniteralnego odstępstwa i późniejszej kary ${ }^{13}$. Warunek ten można zapisać jako:

$$
\frac{1}{1-\delta} \pi_{i}^{Z} \geq \pi_{i}^{O}+\frac{\delta}{1-\delta} \pi_{i}^{N C}
$$

W przypadku sformułowanej wyżej gry składowej $g$ najistotniejsza jest modyfikacja strategii (18) uwzględniająca przyjęty, stały system kwot kartelowych $s_{i}$. Należy wyraźnie zaznaczyć bezpośrednią zależność wyborów graczy od wysokości kwot kartelowych, reformułując (18) jako:

$$
S_{i}=\left\{\begin{array}{c}
q_{i}^{t}=q_{i}^{z}\left(s_{i}\right), \quad g d y \quad q_{j}^{\tau}=q_{j \neq i}^{z}\left(1-s_{i}\right) \quad \text { dla } \tau=0, \ldots, t-1 \\
q_{i}^{t}=q_{i}^{N C} \\
q_{j}^{\tau}=q_{j \neq i}^{O}\left(1-s_{i}\right) \quad \text { dla } \tau=0, \ldots, t-1,
\end{array}\right.
$$

gdzie: $s_{i}=s_{i}^{0}=$ const.

Zasadniczym pytaniem jest, czy wybory zmowy graczy oparte na egzogenicznie predefiniowanej w momencie rozpoczęcia gry strukturze kwot kartelowych konstytuują stacjonarną ścieżkę wyborów, a więc czy strategie przełącznikowe (20) są w równowadze doskonałej dla podgier supergry. Pochodną kwestią jest to, czy istnieje graniczna (minimalna) kwota kartelowa $s_{i}$, przy której gracz jest skłonny uczestniczyć w zmowie. Aby to zbadać, wykorzystamy warunek (19). Dla zdefiniowanych uprzednio wypłat gry $g$ przyjmie on postać:

$$
\frac{1}{1-\delta} \frac{1}{4 b} s_{i}(a-c)^{2} \geq \frac{1}{16 b}(a-c)^{2}\left(s_{i}+1\right)^{2}+\frac{\delta}{1-\delta} \frac{(a-c)^{2}}{(n+1)^{2} b} .
$$

Nierówność ta jest zachowana dla:

$$
s_{i} \geq-\frac{1}{(\delta-1)(n+1)}\left(\delta+n-2 \sqrt{\delta} \sqrt{4 \delta+2 n+n^{2}-3}+\delta n+1\right) .
$$

(22) pociąga za sobą następujące stwierdzenie:

\section{Stwierdzenie 1}

Strategie (20) zdefiniowane dla supergry i wypłat gry składowej (6), (10), (14) są w równowadze doskonałej dla podgier, jeśli kwota kartelowa gracza $i$ jest nie mniejsza niż (22). Oznacza to, iż dla ustalonego współczynnika dyskonta oraz

13 Jest to ogólnie znana konkluzja wynikająca z tzw. Twierdzeń Ludowych dla supergier. Twierdzenie dla preferencji z dyskontem i kary Nasha jest następujące: Dla każdego wykonywalnego, silnie indywidualnie racjonalnego wektora wypłat $\mathrm{v}$ gry składowej istnieje $\delta<1$ takie, że dla wszystkich $\delta \in(\delta, 1)$ istnieje równowaga Nasha gry powtarzanej w nieskończonym horyzoncie $\Gamma$ (T) z profilem wypłat v. Dowód: Fundenberg, Tirole (1996). 
liczby graczy w branży istnieje minimalna wartość udziału w rynku s, przy której gracz jest skłonny przystąpić do zmowy lub zachować uczestnictwo w zmowie.

Zauważyć należy, że dla przyjętego modelu liniowego $s_{i}$ zależy jedynie od wartości $\delta$ oraz $n$. Zależność ta jest odwrotnie proporcjonalna, to znaczy, im gracze bardziej cierpliwi, tzn. $\delta$ rośnie do 1 (przy ustalonym $n$ ), lub też im liczba graczy większa przy ustalonym $\delta$, tym graniczna wartość $s_{i}$ mniejsza ${ }^{14}$.

Konkludując ten etap badań, trzeba odnieść się do zachowania graczy w branży producentów Lysiny. Jeśli przyjmie się, iż mechanizm zmowy polegał głównie na ustaleniu udziałów w rynku, graniczną wartością dla 4 graczy (rynek amerykański) oraz współczynnika dyskonta na poziomie 0,98 (wartość ta odpowiada miesięcznemu okresowi detekcji, zgodnemu z częstością danych, oraz stopie procentowej w wysokości $24 \%$ ) jest udział na poziomie $16,357 \%$. Stąd ADM, wchodząc do branży i wiedząc, jaki mechanizm w niej obowiązuje, musiał uzyskać udział w rynku co najmniej na poziomie 16\%. Jedyną drogą do zamiany zastanego status quo była wojna cenowa. Wydaje się więc, iż udało się znaleźć teoretyczną motywację takiego zachowania graczy w początkowej fazie trwania kartelu.

\subsection{MODEL GRY ZMOWY CZĘŚCIOWEJ}

Równowaga supergry z ceną odpowiadającą zagregowanej podaży monopolu dla branży jest niezwykle interesująca z uwagi na wyżej wyprowadzona, jasną zależność skłonności do zawarcia/utrzymania zmowy od liczby graczy i czynnika dyskonta. Jest to jednak równowaga idealna, w praktyce należy oczekiwać, że zagregowana podaż branży będzie nieco wyższa niż podaż monopolowa (np. z uwagi na zakłócenia w przepływie informacji pomiędzy graczami w kartelu lub próby oszustwa). Interesujące jest zatem pytanie, co wpływa na równowagę supergry w przypadku, kiedy cena rynkowa jest pewną częścią ceny monopolowej.

\section{Gra skladowa $g$}

Rynek jest opisany funkcjami liniowymi jak w modelu zmowy całkowitej. Załóżmy, iż przeciętna cena rynkowa w branży odpowiada podaży wyższej niż podaż monopolu, a więc jest dana jako pewna, $r$-ta część ceny monopolowej:

$$
p=r\left[a-b\left(\frac{a-c}{2 b}\right)\right]=r \frac{a+c}{2},
$$

gdzie: $r \in(0 ; 1]$.

14 Nieskomplikowane przekształcenia dowodzące tych stwierdzeń pominięto. 
Podaż i wypłata kary dane są zależnościami (5) i (6). Modyfikacji ulegną podaże i wypłaty zmowy oraz odstępstwa. Zauważmy, iż podaż zmowy, odpowiadająca cenie będącej $r$-tą częścią ceny monopolowej i kontyngentowi $s_{i}$ gracza, określona jest jako:

$$
q_{i}^{z}=s_{i}\left(\frac{a-\left(\frac{1}{2} r(a+c)\right)}{b}\right)=-\frac{1}{b} s_{i}\left(\frac{1}{2} a r-a+\frac{1}{2} c r\right),
$$

a odpowiadająca tej podaży wypłata dla strategii zmowy dana jest jako:

$$
\pi_{i}^{z}=\frac{1}{4 b} s_{i}\left(a^{2} r^{2}-2 a^{2} r+2 a c r^{2}-4 a c r+4 a c+c^{2} r^{2}-2 c^{2} r\right) .
$$

Podaże kartelowe $q_{i}^{z}$ nie są profilem w równowadze Nasha gry składowej. Korzystając z (12), zdefiniujmy funkcję wypłaty:

$$
\pi_{i}=\left[\left(a-b\left(q_{i}+\left(1-s_{i}\right)\left(\frac{a-\left(\frac{1}{2} r(a+c)\right)}{b}\right)\right)\right] * q_{i}-c q_{i} .\right.
$$

Różniczkując (26) ze względu na $q_{i}$ i rozwiązując warunek I rzędu, otrzymujemy najlepszą odpowiedź gracza $i$ :

$$
q_{i}^{O}=-\frac{1}{4 b}\left(2 c-a r-2 a s_{i}-c r+a r s_{i}+c r s_{i}\right) .
$$

Jest to podaż odstępstwa gracza o kontyngencie $s_{i}$ przy założeniu, że nie stosuje on tego kontyngentu, ale pozostali gracze stosują odpowiadające im kwoty kartelowe $\left(1-s_{i}\right)$. Podaży tej odpowiada wypłata odstępstwa:

$$
\pi_{i}^{O}=\frac{1}{16 b}\left(2 c-a r-2 a s_{i}-c r+a r s_{i}+c r s_{i}\right)^{2} .
$$

Przyjmując parametryzację de Roos oraz $r=0,9$, otrzymujemy: $\pi^{N C}=0,921 ; \pi^{Z}=1,064 ; \pi^{O}=1,2491$, co jest zgodne $\mathrm{z}$ teorią.

\section{Gra powtarzana $\Gamma(\mathrm{T})$}

Gra powtarzana ma identyczną konstrukcję jak w modelu zmowy całkowitej. Testując warunki równowagi strategii typu (20), oprzemy się na warunku (19), który dla wypłat gry składowej określonych przez (6), (25) i (28) ma postać:

$$
\begin{aligned}
& \frac{1}{4 b} \frac{s_{i}}{\delta-1}\left(a^{2} r^{2}-2 a^{2} r+2 a c r^{2}-4 a c r+4 a c+c^{2} r^{2}-2 c^{2} r\right) \geq \\
& \geq \frac{1}{16 b}\left(2 c-a r-2 a s_{i}-c r+a r s_{i}+c r s_{i}\right)^{2}+\left(-\frac{1}{b} \delta \frac{(a-c)^{2}}{(\delta-1)(n+1)^{2}}\right) .
\end{aligned}
$$


Warunek (29) można przekształcić w równość i rozwiązać ze względu na $s_{i^{*}}$ Graniczna wartość kwoty kartelowej, dla której strategie typu (20) konstytuują równowage, jest dana jako:

$$
\begin{aligned}
& s_{i}=\frac{1}{(\sqrt{\delta}-1)(\sqrt{\delta}+1)(n+1)(-2 a+a r+c r)}\left(-2 c-2 \sqrt{\delta}\left(4 a^{2} \delta+4 c^{2} \delta+8 c^{2} n-\right.\right. \\
& -4 c^{2} r+4 c^{2} n+a^{2} r^{2}+c^{2} r^{2}+8 a c-4 a^{2}+a^{2} r^{2} n^{2}+c^{2} r^{2} n^{2}+2 a c r^{2}-8 c^{2} n r+ \\
& +2 a^{2} n r^{2}+2 c^{2} n r^{2}-4 c^{2} n^{2} r-8 a c \delta-4 a c r+4 a c r n^{2}-4 a c n^{2} r+2 a c n^{2} r^{2}- \\
& -8 a c n r)^{1 / 2}-2 c \delta-2 c n+a r+c r-2 c \delta n+a \delta r+c \delta r+a n r+c n r+a \delta n r+ \\
& +c \delta n r .
\end{aligned}
$$

Formuła ta pozwala ocenić, iż w przypadku zmowy częściowej minimalny akceptowalny poziom kontyngentu zmowy gracza zależy już nie tylko od liczby graczy i współczynnika dyskonta, ale także od rozmiaru rynku $a$, kosztu $c$ i wysokości ceny rynkowej zmowy $r$. W szczególności niezwykle ważne jest ustalenie, jaki wpływ na akceptowalny dla gracza chcącego pozostać w zmowie ze stałym kontyngentem $s_{i}$ poziom ceny $r$ ma zmiana wielkości rynku $a$. Aby zbadać ten wpływ, należy rozwiązać warunek (29) ze względu na $r$. Wykonując niezbędne kalkulacje, otrzymujemy:

$$
\begin{aligned}
& r=\frac{1}{(n+1)(a+c)\left(-\delta+2 s_{i}-\delta s_{i}^{2}+2 \delta s_{i}+s_{i}^{2}+1\right)}\left(2 c+2 a s_{i}^{2}-4 a\left(-\delta-2 \delta^{2} s_{i}+\right.\right. \\
& \left.+\delta^{2} s_{i}^{2}-2 \delta s_{i}+\delta^{2}+2 \delta n s_{i}^{2}+\delta n^{2} s_{i}^{2}\right)^{1 / 2}+4 c\left(-\delta-2 \delta^{2} s_{i}+\delta^{2} s_{i}^{2}-2 \delta s_{i}+\delta^{2}+\right. \\
& \left.+2 \delta n s_{i}^{2}+\delta n^{2} s_{i}^{2}\right)^{1 / 2}-2 c \delta+2 c n+2 a s_{i}+2 c s_{i}-2 a \delta s_{i}^{2}+2 a n s_{i}^{2}-2 c \delta n+2 a \delta s_{i}+ \\
& +2 c \delta s_{i}+2 a n s_{i}+2 c n s_{i}-2 a \delta n s_{i}^{2}+2 a \delta n s_{i}+2 c \delta n s_{i} .
\end{aligned}
$$

Aby ocenić wpływ fluktuacji rozmiaru rynku $a$, zbadajmy graniczne zachowanie (31) w przypadku kurczenia się rynku do poziomu $c$ :

$$
\begin{aligned}
& \lim _{a \rightarrow c} r=\frac{1}{2 c(n+1)\left(-\delta+2 s_{i}-\delta s_{i}^{2}+2 \delta s_{i}+s_{i}^{2}+1\right)} 2 c+2 c s_{i}^{2}-2 c \delta+2 c n+4 c s_{i}- \\
& -2 c \delta s_{i}^{2}+2 c n s_{i}^{2}-2 c \delta n+4 c \delta s_{i}+4 c n s_{i}-2 c \delta n s_{i}^{2}+4 c \delta n s_{i}=1
\end{aligned}
$$

oraz zwiększania się rynku do $+\infty$ :

$$
\begin{aligned}
& \lim _{a \rightarrow \infty} r=\frac{1}{(n+1)\left(-\delta+2 s_{i}-\delta s_{i}^{2}+2 \delta s_{i}+s_{i}^{2}+1\right)}\left(2 s_{i}-4\left(-\delta-2 \delta^{2} s_{i}+\right.\right. \\
& \left.+\delta^{2} s_{i}^{2}-2 \delta s_{i}+\delta^{2}+2 \delta n s_{i}^{2}+\delta n^{2} s_{i}^{2}\right)^{1 / 2}+2 s_{i}^{2}-2 c \delta+2 n s_{i}-2 \delta s_{i}+ \\
& +2 n s_{i}^{2}-2 \delta n s_{i}^{2}+2 \delta n s_{i} .
\end{aligned}
$$

Wartość granicy (33) można oszacować numerycznie, stosując np. parametryzację de Roos. Jest ona wtedy równa 0,592.

Z (32) oraz (33) można wyprowadzić następujące stwierdzenie: 


\section{Stwierdzenie 2}

Jeśli rozmiar rynku się zwiększa, to przy ustalonej strukturze kwot kartelowych $s_{i}$ cena wystarczająca do utrzymania zmowy maleje. Oczywiście gracze nie byliby rozsądni, aby cenę tę obniżać poza aktualny poziom $r$ wystarczający do utrzymania zmowy. Jednak jeśli rynek kurczy się, to aby utrzymać skłonność gracza $i$ o minimalnym udziale w rynku min $s_{i}$ do utrzymania zmowy, cena rynkowa nie może być proporcjonalnie niższa (i utrzymywana na przyjętym poziomie $r$-tej części ceny monopolowej), lecz musi zachować pewną sztywność.

Stwierdzenie powyższe oferuje teoretyczne uzasadnienie niższej wariancji średniej ceny rynkowej w okresie zmowy - cena podąża za wzrostem rynku, lecz zachowuje sztywność w przypadku kurczenia się go, tak aby zachować skłonność do pozostania w zmowie gracza o najniższej kwocie kartelowej.

\section{PODSUMOWANIE}

Podsumowując część pierwszą pracy, można stwierdzić, iż model supergry ze stałą strukturą kwot kartelowych wskazuje na:

- możliwość wystapienia fazy wojny cenowej, wywołanej przez gracza niemającego intencji utrzymania lub nawiązania zmowy ze względu na zbyt niski przewidywany lub faktyczny udział w rynku,

- $\quad$ średnio niższą wariancję ceny rynkowej w fazie zmowy, spowodowaną sztywnością cen w okresach kurczenia się rynku.

Model taki może służyć do wyjaśnienia, między innymi, zachowań graczy w branży producentów Lysiny w latach 1990-1996. Model ten teoretycznie wspiera metodę detekcji zmowy opartą na analizie wariancji procesu ceny rynkowej, wskazując na możliwość zmian reżimowych wariancji przy przejściu z fazy wojny cenowej (możliwej na ścieżce równowagi) do fazy zmowy oraz przeciętnie niższą wariancję ceny $\mathrm{w}$ fazie zmowy, związaną $\mathrm{z}$,wygładzaniem ceny” w okresach kurczenia się rynku.

\section{LITERATURA}

Abrantes-Metz R., Froeb L., Geweke J., Taylor C. (2006), A variance screen for collusion, „International Journal of Industrial Organization”, 24, 467-486.

Athey S., Bagwell K. (2001), Optimal collusion with private information, „RAND Journal of Economics”, 32(3), 428-465.

Athey S., Bagwell K., Sanchirico C. (2004), Collusion and price rigidity, „Review of Economic Studies”, 71, 317-349. 
Bejger S. (2009a), Ekonometryczne narzędzia detekcji równowagi zmowy w branży, „Acta Universitatis Nicolai Copernici. Ekonomia”, 39, s. 125.

Bejger S. (2009b), Zawodność rynków - zmowa graczy. Metody detekcji w świetle polityki konkurencji, „Ekonomia i Prawo”, 5, s. 247-161.

Bolotova Y., Connor J. M., Miller D. J. (2008), The impact of collusion on price behavior: Empirical results from two recent cases, „International Journal of Industrial Organization”, 26, 1290-1307.

Connor J. (2000), Archer Daniels Midland: Price-fixer to the World, Staff paper No. 00-11, Department of Agricultural Economics, Purdue University, West Lafayette, IN.

Connor J. (2001), „Our customers are our enemies”: the lysine cartel of 1992-1995, „Review of Industrial Organization”, 18, 5-21.

de Roos N. (2004), A model of collusion timing, „International Journal of Industrial Organization”, 22, 351-387.

de Roos N. (2006), Examining models of collusion: The market for lysine, „International Journal of Industrial Organization”, 24, 1083-1107.

Fundenberg D., Tirole J. (1996), Game theory, MIT Press, Cambridge.

Green E., Porter R. (1984), Non-cooperative collusion under imperfect price information, „Econometrica”, 52, 87-100.

Griffin J. M. (2001), An inside look at a cartel at work: Common characteristics of internationals cartels, [w:] Fighting cartels - why and how?. Proceedings of the $3^{\text {rd }}$ Nordic Competition Policy Conference, Stockholm.

Haltiwanger J., Harrington J. E. (1991), The Impact of Cyclical Demand Movements on Collusive Behavior, „RAND Journal of Economics”, 22, 89-106.

Ishibashi I. (2008), Collusive price leadership with capacity constraints, „International Journal of Industrial Organization”, 26, 704-715.

Knittel Ch. R., Lepore J. J. (2010), Tacit collusion in the presence of cyclical demand and endgenous capacity levels, „International Journal of Industrial Organization”, 28, 131-144.

Leufkens K., Peeters R. (2009), Price dynamics and collusion under short run price commitments, article in press in „International Journal of Industrial Organization”.

Markham J. (1951), The Nature and Signifi ance of Price Leadership, „American Economic Review”, 41.

Maskin E., Tirole J. (1988), A theory of dynamic oligopoly II, „Econometrica”, 56, 571-599.

Rotemberg J., Saloner G. (1986), A supergame theoretic model of business cycles and price wars during booms, „American Economic Review”, 76, 390-407.

Rotemberg J., Saloner G. (1990), Collusive price leadership, „The Journal of Industrial Economics”, 39, 93-111.

Yuanzhu L., Wright J. (2009), Tacit collusion with price-matching punishments, article in press in „International Journal of Industrial Organization”. 


\title{
DETECTION OF COLLUSION \\ IN AN INDUSTRY WITH APPLICATION \\ OF WAVELET ANALYSIS - THEORETICAL MODEL
}

\begin{abstract}
A b stra ct. In this paper a supergame model of collusion based on fixed cartel quota exogenously provided by cartel members' agreement is developed. The model provides theoretical motivation of price wars and variance screen of collusion. We use the model to explain behavior of well known Lysine conspiracy members. In a second part of a research we will verify usefulness of a variance marker in an empirical example with application of wavelet analysis.
\end{abstract}

K e y w o r d s : explicit and tacit collusion, supergames, cartel detection, Lysine, price variance, wavelet analysis. 